\title{
Scorpaena dabryi, a Junior Synonym of Scorpaena miostoma, with Notes on Morphological Ontogenetic Changes (Teleostei: Scorpaenidae)
}

\author{
Kunto Wibowo ${ }^{1,2,4}$ and Hiroyuki Motomura ${ }^{3}$ \\ ${ }^{1}$ The United Graduate School of Agricultural Sciences, Kagoshima University, 1-21-24 Korimoto, Kagoshima 890-0065, Japan \\ E-mail:kuntowe@gmail.com \\ ${ }^{2}$ Research Center for Oceanography, LIPI, Jl. Pasir Putih I, Ancol Timur, Jakarta 14430, Indonesia \\ ${ }^{3}$ The Kagoshima University Museum, 1-20-31 Korimoto, Kagoshima 890-0065, Japan \\ E-mail:motomura@kaum.kagoshima-u.ac.jp \\ ${ }^{4}$ Corresponding author
}

(Received 19 April 2019; Accepted 12 June 2019)

\begin{abstract}
Although Scorpaena dabryi Sauvage, 1878, originally described on the basis of two specimens from China, has recently been regarded as a senior synonym of Neomerinthe procurva Chen, 1981, examination of the specimens (herein designated as lectotype of $S$. dabryi) showed them to be consistent with the holotype and non-type specimens of $S$. miostoma Günther, 1877. Accordingly, S. dabryi is regarded as a junior synonym of S. miostoma. Morphological ontogenetic changes of some body proportions in S. miostoma are also described.
\end{abstract}

Key Words: Scorpionfish, taxonomy, distribution, East Asia.

\section{Introduction}

Scorpaena dabryi Sauvage, 1878, was originally described from two specimens collected from China. Since the original description there have been no further reports of the species, except for a comment in Fricke et al. (2019), which indicated that it was a synonym of Neomerinthe procurva Chen, 1981. However, examination of the two syntypes and original description of $S$. dabryi during the present study revealed their close agreement with characters of Indo-Pacific species of Scorpaena, given by Poss (1999) and Motomura et al. (2005b, 2006, 2007), viz., 12 dorsal-fin spines, teeth on the palatines, an occipital pit, some pectoral-fin rays branched, and the pored lateral-line scales continuing onto the caudal-fin base. Further comparison of the type specimens with individuals of Scorpaena showed them to be conspecific with S. miostoma Günther, 1877.

\section{Materials and Methods}

Counts and measurements generally followed Motomura (2004a, b), with several additional counts and measurements following Motomura et al. (2005a, b, 2006). The last two soft rays of the dorsal and anal fins were counted as single rays, each pair being associated with a single pterygiophore. Standard length is expressed as SL. Terminology of head spines follows Randall and Eschmeyer (2002: fig. 1) and Motomura (2004b: fig. 1), with the following additions: supplemental preopercular spine-a spine at the base of the uppermost preopercular spine (Eschmeyer 1965); lateral lacrimal spine-the spine on the lateral surface of the lacrimal bone (Motomura and Senou 2008: fig. 2). The coronal and pretympanic spines are as figured by Chen (1981: fig. 1) and Motomura et al. (2004: fig. 14b), respectively. The sex was confirmed by dissection of the right side of the abdomen. Institutional codes follow Sabaj (2016). Standard names of specimen localities collected from Taiwan follow Ebert et al. (2013: table 5).

Type material examined in this study included: $\mathrm{BMNH}$ 1879.5.14.235, holotype of Scorpaena miostoma, $106.4 \mathrm{~mm}$ SL, market in Yokohama, Kanagawa, Japan, collected during the H.M.S. Challenger Expedition; MNHN 6882, lectotype of Scorpaena dabryi (designated herein), male, $75.5 \mathrm{~mm} \mathrm{SL}$, China, D. Thiersant; MNHN 6882, paralectotype of $S$. dabryi, sex unknown, $71.0 \mathrm{~mm}$ SL, same data as lectotype. The following non-type specimens of S. miostoma (139 specimens, $21.5-133.4 \mathrm{~mm}$ SL) were also examined: CHINA: CAS $66631,84.9 \mathrm{~mm} \mathrm{SL}$, south of Hong Kong, $21^{\circ} 00^{\prime} \mathrm{N}$, $113^{\circ} 32^{\prime} \mathrm{E}, 450 \mathrm{~m}$, otter trawl, F. Ommanney on FRV Alister Hardy, 26 June 1958; CAS-SU 61032, 2, 84.0-104.3 mm SL, off Shing Shi Mun, Hong Kong, $22^{\circ} 11^{\prime} 55^{\prime \prime} \mathrm{N}, 114^{\circ} 15^{\prime} 00^{\prime \prime} \mathrm{E}$, otter trawl, R. Bolin on FRV Alister Hardy, 8 January 1958; CAS-SU 32428, $76.8 \mathrm{~mm}$ SL, Chusan Island, Tianghai, Zhejiang, $32^{\circ} 18^{\prime} 32.6^{\prime \prime} \mathrm{N}, 121^{\circ} 25^{\prime} 12.4^{\prime \prime} \mathrm{E}$, A. Herre, 5 October 1936; CAS-SU 25753, 73.8 mm SL, Guangzhou, Guangdong, A. Herre, September 1931; USNM 20438, $57.3 \mathrm{~mm}$ SL, W. Stimpson, 14 August 1877. KOREA/JAPAN: CAS 17558, 2 specimens, $54.0-82.8 \mathrm{~mm} \mathrm{SL}$, southeast of Cheju Do, Korea and west of Kyushu, Japan, F. Steiner, December 1971. JAPAN: BSKU 19614, male, $94.5 \mathrm{~mm}$ SL, Uraga Channel, Kanagawa, 35 ${ }^{\circ} 10^{\prime} 0^{\prime \prime} \mathrm{N}, 139^{\circ} 42^{\prime} 6^{\prime \prime} \mathrm{E}, 48-62$ m, 30 March 1965; BSKU 39331, $123.5 \mathrm{~mm}$ SL, BSKU 39338, male, $67.8 \mathrm{~mm}$ SL, 
Tosa Bay, Kochi, trawl, 9 June 1983; BSKU 39373, male, 106.5 mm SL, 25 June 1983, other data as for BSKU 39331; BSKU 39888, 114.0 mm SL, Tosa Bay, Kochi, 14-15 March 1984; BSKU 40476, 108.6 mm SL, off Nagasaki, 23 November 1984; BSKU 41752, male, 100.7 mm SL, Tosa Bay, Kochi, set net, 7 May 1985; BSKU 41760, 78.4 mm SL, BSKU 41765, male, $104.3 \mathrm{~mm}$ SL, BSKU 41767, male, $114.6 \mathrm{~mm}$ SL, Urado Bay, Kochi, 40-50 m, trawl, 13 May 1985; BSKU 41771, male, $89.5 \mathrm{~mm}$ SL, Tosa Bay, Kochi, 30-50 m, trawl, 16 May 1985; BSKU 41787, 92.9 mm SL, Uranouchi Bay, Kochi, 20 May 1985; BSKU 42583, 99.8 mm SL, Tosa Bay, Kochi, 8 April 1986; BSKU 65649, $57.1 \mathrm{~mm}$ SL, Uranouchi Bay, Kochi, hand net, 5 August 2003; BSKU 91353, 57.0 mm SL, Tosa Bay, Kochi, 27 June 2007; BSKU 125646, 87.0 mm SL, BSKU 125647, $102.8 \mathrm{~mm}$ SL, Tosa Bay, Kochi, 1970; BSKU 125648, male, $117.7 \mathrm{~mm} \mathrm{SL}$, precise locality unknown; BSKU 125649, male, $131.0 \mathrm{~mm}$ SL; CAS 219761, $98.0 \mathrm{~mm}$ SL, Osaka Bay, Kobe, $34^{\circ} 29^{\prime} 53.5^{\prime \prime} \mathrm{N}, 135^{\circ} 11^{\prime} 03.0^{\prime \prime} \mathrm{E}$, D. Jordan and J. Snyder, 1900; CAS-SU 23547, $88.9 \mathrm{~mm} \mathrm{SL}$, off Misaki, Miura, Yokosuka, $35^{\circ} 08^{\prime} 26.6^{\prime \prime} \mathrm{N}, 139^{\circ} 36^{\prime} 43.0^{\prime \prime} \mathrm{E}, \mathrm{K}$. Aoki; CMNH-ZF 16001, $50.4 \mathrm{~mm}$ SL, Masaki, Shimizu, Shizuoka, $35^{\circ} 01^{\prime} 10^{\prime \prime} \mathrm{N}, 138^{\circ} 31^{\prime} 32^{\prime \prime} \mathrm{E}$, hand net, Y. Ikeda and M. Aizawa, 12 October 2006; CMNH-ZF 7048, 21.5 mm SL, off Sanamijima Island, Kamogawa, Chiba, hand net, J. Okuno, 1 October 2003; FRLM 3917, 129.4 mm SL, Ago Bay, Shimacho Goza, Shima, Mie, S. Kimura et al., 2 May 1982; FRLM $5790,118.6 \mathrm{~mm} \mathrm{SL}, 31$ October 1986, other data as for FRLM 3917; FRLM 6386, $97.4 \mathrm{~mm}$ SL, precise locality unknown, S. Kimura et al., 10 April 1987; FRLM 11012, $117.6 \mathrm{~mm}$ SL, off Kumano-nada, Shimacho Wagu, Shima, Mie, 17 March 1991; FRLM 14373, 94.2 mm SL, Ago Bay, Shimacho Goza, Shima, Mie, $34^{\circ} 16^{\prime} 56.3^{\prime \prime} \mathrm{N}$, $136^{\circ} 45^{\prime} 15.5^{\prime \prime} \mathrm{E}-34^{\circ} 17^{\prime} 01.7^{\prime \prime} \mathrm{N}, \quad 1^{\circ} 6^{\circ} 46^{\prime} 19.2^{\prime \prime} \mathrm{E}, 24$ August 1995; KAUM-I. 10014, male, $124.4 \mathrm{~mm}$ SL, KAUM-I. 10015, 100.3 mm SL, off Kawajiri Fishing Port, Ibusuki, Kagoshima, $31^{\circ} 10^{\prime} \mathrm{N}, 130^{\circ} 32^{\prime} \mathrm{E}, 100-120 \mathrm{~m}$, set net, G. Ogihara and T. Yoshida, 4 June 2008; KAUM-I. 10766, $47.1 \mathrm{~mm} \mathrm{SL}$, KAUM-I. 10767, 44.4 mm SL, east of Sakinoyama, Kasasa, Kagoshima, $31^{\circ} 25^{\prime} 44^{\prime \prime} \mathrm{N}, 130^{\circ} 11^{\prime} 49^{\prime \prime} \mathrm{E}, 27 \mathrm{~m}$, set net, M. Ito, 2 July 2008; KAUM-I. 17388, male, $83.1 \mathrm{~mm}$ SL, KAUM-I. 17389, $58.1 \mathrm{~mm}$ SL, off Takane, Tateyama, Chiba, $34^{\circ} 58^{\prime} 38^{\prime \prime} \mathrm{N}, 139^{\circ} 47^{\prime} 19^{\prime \prime} \mathrm{E}, 20 \mathrm{~m}$, hand net, M. Aizawa, 10 December 2008; KAUM-I. 20016, male, $57.1 \mathrm{~mm} \mathrm{SL}$, off Kozakiyama, Kasasa, Kagoshima, $31^{\circ} 26^{\prime} 00^{\prime \prime} \mathrm{N}, 130^{\circ} 10^{\prime} 05^{\prime \prime} \mathrm{E}$, $36 \mathrm{~m}$, set net, M. Ito, 3 November 2008; KAUM-I. 20710, male, $82.2 \mathrm{~mm} \mathrm{SL}, 11$ August 2008, other data as for KAUM-I. 20016; KAUM-I. 21028, 94.8 mm SL, off Kasumi, Kami, Hyogo, $35^{\circ} 39^{\prime} \mathrm{N}, 134^{\circ} 37^{\prime} \mathrm{E}, 200 \mathrm{~m}$, trawl, T. Wada, 16 May 2007; KAUM-I. 22718, 133.4 mm SL, KAUM-I. 22719, $114.7 \mathrm{~mm}$ SL, off Kushima, Uwajima, Ehime, $33^{\circ} 13^{\prime} 23^{\prime \prime} \mathrm{N}$, $132^{\circ} 52^{\prime} 50^{\prime \prime} \mathrm{E}, 10 \mathrm{~m}$, gill net, S. Kyoue, 2 August 2003; KAUM-I. 25862, 62.3 mm SL, off Field Science Center, Tateyama, Chiba, $34^{\circ} 58^{\prime} 37^{\prime \prime} \mathrm{N}, 139^{\circ} 46^{\prime} 10^{\prime \prime} \mathrm{E}, 7 \mathrm{~m}$, hand net, $\mathrm{M}$. Watai, 10 November 2009; KAUM-I. 30794, male, $95.9 \mathrm{~mm}$ SL, KAUM-I. 30795, $112.2 \mathrm{~mm}$ SL, KAUM-I. 30796, 108.2 mm SL, KAUM-I. 30797, male, 99.9 mm SL, Shibushi Bay, Shibushi, Kagoshima, $31^{\circ} 38^{\prime} \mathrm{N}, 131^{\circ} 14^{\prime} \mathrm{E}, 100-120$, trawl, G. Ogihara et al., 7 July 2010; KAUM-I. 38820, fe- male, $114.2 \mathrm{~mm}$ SL, off Ibusuki, Kagoshima, $31^{\circ} 12^{\prime} 05^{\prime \prime}-$ $13^{\circ} 09^{\prime} \mathrm{N}, 130^{\circ} 40^{\prime} 05^{\prime \prime}-41^{\circ} 08^{\prime} \mathrm{E}, 50-60 \mathrm{~m}$, line-fishing, Y. Masuda, 20-21 June 2011; KAUM-I. 38862, male, $90.4 \mathrm{~mm} \mathrm{SL}$, Uchinoura Bay, Kimotsuki, Kagoshima, $31^{\circ} 17^{\prime} \mathrm{N}, 131^{\circ} 05^{\prime} \mathrm{E}$, 0-40, set net, M. Yamada, 22 February 2011; KAUM-I. 43931, male, $85.5 \mathrm{~mm} \mathrm{SL}$, Tosa Bay, Irino, Kochi, $33^{\circ} 00^{\prime} \mathrm{N}$, $133^{\circ} 01^{\prime} \mathrm{E}, 50-100 \mathrm{~m}$, trawl, M. Matsunuma and N. Nakayama, 15 December 2011; KAUM-I. 56305, $73.5 \mathrm{~mm} \mathrm{SL,} 8$ April 2013, other data as for KAUM-I. 10766; KAUM-I. 57301, male, $41.4 \mathrm{~mm}$ SL, Uchinoura Bay, Kimotsuki, Kagoshima, $31^{\circ} 17^{\prime} \mathrm{N}, 131^{\circ} 05^{\prime} \mathrm{E}, 40 \mathrm{~m}$, set net, M. Yamada, 23 July 2013; KAUM-I. 71264, male, 43.8 mm SL, Uchinoura Bay, Kimotsuki, Kagoshima, $31^{\circ} 17^{\prime} 29^{\prime \prime} \mathrm{N}, 131^{\circ} 06^{\prime} 59^{\prime \prime} \mathrm{E}$, set net, 30-35 m, K. Koeda et al., 23 March 2015; KAUM-I. 71449, male, $81.5 \mathrm{~mm}$ SL, Uchinoura Bay, Kimotsuki, Kagoshima, $31^{\circ} 16^{\prime} 55^{\prime \prime} \mathrm{N}, 131^{\circ} 04^{\prime} 49^{\prime \prime} \mathrm{E}, 30-35 \mathrm{~m}$, set net, $\mathrm{T}$. Yanagigawa, January-February 2015; KAUM-I. 77849, male, $80.4 \mathrm{~mm}$ SL, M. Yamada, 12 June 2015, other data as for KAUM-I. 71449; KAUM-I. 80376, female, $51.8 \mathrm{~mm}$ SL, off Koyama, Kimotsuki, Kagoshima, $31^{\circ} 21^{\prime} \mathrm{N}, 131^{\circ} 02^{\prime}$ E, set net, K. Koeda and H. Hata, 21 October 2015; KAUM-I. 83236, male, $42.0 \mathrm{~mm} \mathrm{SL}, 9$ August 2015, other data as for KAUM-I. 10766; OMNH-P 6431, 120.9 mm SL, off Mio, Hamasaka, Hyogo; OMNH-P 7833, 104.1 mm SL, off Okami Park, Hyogo; OMNH-P 8597, 87.4 mm SL, OMNH-P 8598, male, $93.0 \mathrm{~mm}$ SL, OMNH-P 8793, male, $92.5 \mathrm{~mm}$ SL, Osaka Bay, Misaki, Osaka; OMNH-P 9455, 95.3 mm SL, off Tanigawa, Misaki, Osaka; OMNH-P 10620, male, $116.4 \mathrm{~mm}$ SL, off Iyo, Iyo Nada, Ehime. TAIWAN: ASIZP 63629, $76.1 \mathrm{~mm}$ SL, Da-xi, Yilan county, $24^{\circ} 95^{\prime} \mathrm{N}, 121^{\circ} 93^{\prime} \mathrm{E}, 50 \mathrm{~m}$, Z.-H. Wu, 23 March 2000; CAS 219760, 88.8 mm SL, Taiwan Strait, 90 m, trawl, F. Steiner, April 1971; KAUM-I. 9934, 127.6 mm SL, KAUM-I. 9935, 103.8 mm SL, off Da-xi, Yilan county, $24^{\circ} 59^{\prime} \mathrm{N}, 122^{\circ} 06^{\prime} \mathrm{E}, 400 \mathrm{~m}$, bottom trawl, H. Motomura and H.-C. Ho, 29 May 2008; KAUM-I. 17755, 97.3 mm SL, KAUM-I. 17756, 106.1 mm SL, off Da-xi, Yilan county, bottom trawl, H.-C. Ho, 18 November 2007; KAUM-I. 17758, $90.9 \mathrm{~mm}$ SL, KAUM-I. 17759, $82.5 \mathrm{~mm}$ SL, KAUM-I. $17760,81.6 \mathrm{~mm}$ SL, KAUM-I. 17761, $81.3 \mathrm{~mm}$ SL, KAUM-I. 17762, $74.1 \mathrm{~mm}$ SL, KAUM-I. $17763,74.1 \mathrm{~mm} \quad$ SL, KAUM-I. 17764, $73.3 \mathrm{~mm}$ SL, KAUM-I. 17765, 73.9 mm SL, KAUM-I. 17766, $72.9 \mathrm{~mm}$ SL, KAUM-I. 17767, $67.0 \mathrm{~mm} \mathrm{SL}$, off Dong-Shi, Chiayi county, bottom trawl, H.-C. Ho, 14 November 2008; KAUM-I. 39177, male, 93.9 mm SL, KAUM-I. 39178, male, $92.8 \mathrm{~mm}$ SL, KAUM-I. 39179, $85.6 \mathrm{~mm}$ SL, KAUM-I. 39180, 77.5 mm SL, off Kaohsiung city, trawl, H.-C. Ho, purchased at Tong Kang Fish Market, Kaohsiung city, 1 July 2011; KAUM-I. 39271, 87.9 mm SL, KAUM-I. 39272, $82.2 \mathrm{~mm}$ SL, off Da-xi, Yilan county, $300 \mathrm{~m}$, trawl, KAUM Fish Team, 6 July 2011; KAUM-I. 39611, 131.1 mm SL, off Keelung city, gill net, KAUM Fish Team, purchased at Bisha Fish Market, 10 July 2011; KAUM-I. 44622, 85.1 mm SL, off Kaohsiung city, $400 \mathrm{~m}$, trawl, H.-C. Ho, 7 July 2011; KAUM-I. 44774, male, $93.1 \mathrm{~mm}$ SL, off Da-xi, Yilan county, 500 m, trawl, KAUM Fish Team, 6 July 2011; KAUM-I. 46476, $70.3 \mathrm{~mm}$ SL, KAUM-I. 46477, $61.5 \mathrm{~mm}$ SL, KAUM-I. 46478, 70.6 mm SL, off Da-xi, Yilan county, bot- 
Table 1. Counts and measurements of the lectotype and paralectotype of Scorpaena dabryi, and the holotype and non-type specimens of Scorpaena miostoma (expressed as percentages of standard length).

\begin{tabular}{|c|c|c|c|c|}
\hline & \multicolumn{4}{|l|}{ Scorpaena miostoma } \\
\hline & Lectotype of $S$. dabryi & Paralectotype of S. dabryi & $\begin{array}{l}\text { Holotype of } \\
\text { S. miostoma }\end{array}$ & Non-type specimens \\
\hline & MNHN 6882 & MNHN 6882 & BMNH 1879.5.14.235 & $\mathrm{n}=139$ \\
\hline Standard length (mm) & 75.5 & 71.0 & 106.4 & $21.5-133.4$ \\
\hline \multicolumn{5}{|l|}{ Counts } \\
\hline Dorsal-fin rays & XII, 9 & XII, 9 & XII, 9 & XII, 8-10 (9) \\
\hline Anal-fin rays & III, 5 & III, 5 & III, 5 & III, 5-6 (5) \\
\hline Pectoral-fin rays ${ }^{\mathrm{a}}$ & $\mathrm{ii}+6+v i i i=16 / 17$ & $\mathrm{ii}+5+\mathrm{x}=17 / 17$ & $\mathrm{i}+7+\mathrm{viii}=16 / 16$ & $\begin{array}{c}\mathrm{i}-\mathrm{iii}(\mathrm{i})+2-8(6)+\text { vii-xi } \\
(\mathrm{ix})=15-17(16) / 15-17(16)\end{array}$ \\
\hline Scale rows in longitudinal series & - & - & 44 & $43-47(45$ or 46$)$ \\
\hline Pored lateral-line scales & - & - & 23 & $22-24(23)$ \\
\hline Scales above lateral line & 6 & - & 5 & $5-8(6)$ \\
\hline Scales below lateral line & - & - & 18 & $13-18(14$ or 15$)$ \\
\hline $\begin{array}{l}\text { Scale rows between } 6 \text { th dorsal-fin } \\
\text { spine base and lateral line }\end{array}$ & - & - & 7 & $6-9(7$ or 8$)$ \\
\hline $\begin{array}{l}\text { Scale rows between last dorsal-fin } \\
\text { spine base and lateral line }\end{array}$ & 7 & - & 8 & $6-9(7$ or 8$)$ \\
\hline Pre-dorsal scale rows & 5 & - & 4 & $4-7(5$ or 6$)$ \\
\hline Gill rakers ${ }^{b}$ & $4+8+2=14$ & $5+7+2=14$ & $5+8+2=15$ & $\begin{array}{l}4-6(4 \text { or } 5)+5-9(8)+0-3 \\
(1 \text { or } 2)=12-15(13 \text { or } 14)\end{array}$ \\
\hline \multicolumn{5}{|l|}{ Measurements (\% SL) } \\
\hline Body depth & 33.2 & - & 37.5 & $32.3-39.9(36.1)$ \\
\hline Body width & 19.6 & 18.6 & 24.2 & $19.0-28.2(23.3)$ \\
\hline Head length & 42.6 & 44.4 & 45.2 & $41.7-47.2(44.5)$ \\
\hline Head width & 15.6 & 15.3 & 15.3 & $14.5-16.6(15.6)$ \\
\hline Snout length & 10.2 & 9.7 & 11.2 & $9.6-12.8(11.2)$ \\
\hline Orbit diameter & 13.4 & 13.7 & 13.1 & $11.3-15.3(13.5)$ \\
\hline Interorbital width $^{c}$ & 5.7 & 6.1 & 5.0 & $5.3-7.8(6.5)$ \\
\hline Interorbital width ${ }^{\mathrm{d}}$ & 5.6 & 5.5 & 4.8 & $4.3-6.8(5.7)$ \\
\hline Upper-jaw length & 21.2 & 20.3 & 21.3 & $18.7-23.2(21.2)$ \\
\hline Maxilla depth & 7.2 & 6.5 & 6.9 & $6.3-8.8(7.1)$ \\
\hline Postorbital length & 21.2 & 20.6 & 22.2 & $20.7-23.7(22.3)$ \\
\hline $\begin{array}{l}\text { Between ventral margin of orbit } \\
\text { and suborbital ridge }\end{array}$ & 2.4 & 1.5 & 2.7 & $0.5-3.5(1.6)$ \\
\hline Between tips of opercular spines & 7.4 & 7.0 & 7.7 & $5.3-8.2(6.9)$ \\
\hline Occipital pit length & 4.8 & 5.4 & 5.8 & $4.5-7.0(5.6)$ \\
\hline Occipital pit width & 6.4 & 5.4 & 5.9 & $5.3-7.6(6.5)$ \\
\hline Post-occipital pit & 7.8 & 10.3 & 6.0 & $6.0-11.4(8.3)$ \\
\hline Predorsal-fin length & 35.6 & 37.9 & 35.4 & $32.7-39.2(36.4)$ \\
\hline Preanal-fin length & 75.1 & 71.3 & 73.7 & $67.1-77.2(71.9)$ \\
\hline Prepelvic-fin length & 40.0 & 38.0 & 42.5 & $30.0-44.8(41.0)$ \\
\hline 1st dorsal-fin spine length & 8.1 & 8.7 & - & $7.4-12.0(9.7)$ \\
\hline 2nd dorsal-fin spine length & 14.7 & 15.8 & 11.1 & $12.9-19.7(16.2)$ \\
\hline 3rd dorsal-fin spine length & - & 21.0 & 17.4 & $15.5-24.0(20.0)$ \\
\hline 4th dorsal-fin spine length & 18.7 & 22.1 & 18.9 & $16.3-25.1(20.5)$ \\
\hline 5th dorsal-fin spine length & 18.0 & 20.4 & 18.8 & $16.7-24.0(19.7)$ \\
\hline 6th dorsal-fin spine length & 17.2 & 17.9 & - & $15.1-20.8(18.5)$ \\
\hline 7th dorsal-fin spine length & 15.4 & 18.9 & - & $14.7-19.4(17.3)$ \\
\hline 8th dorsal-fin spine length & 14.6 & 18.0 & - & $14.1-18.1(15.9)$ \\
\hline 9th dorsal-fin spine length & 12.3 & 15.2 & - & $10.0-15.5(13.4)$ \\
\hline 10th dorsal-fin spine length & 10.5 & 12.0 & - & $8.7-13.0(10.7)$ \\
\hline 11th dorsal-fin spine length & 8.2 & 8.7 & 9.7 & $7.6-11.7(10.0)$ \\
\hline 12th dorsal-fin spine length & 14.4 & 15.4 & 14.9 & $12.6-18.8(15.6)$ \\
\hline Longest dorsal-fin soft ray length & - & - & 20.9 & $18.6-23.3(20.9)$ \\
\hline 1st anal-fin spine length & 10.7 & 11.4 & 9.9 & $8.9-14.7(11.7)$ \\
\hline 2nd anal-fin spine length & 21.2 & 23.7 & 19.9 & $17.4-25.8(21.7)$ \\
\hline 3rd anal-fin spine length & - & 19.6 & 16.5 & $14.4-21.7(18.3)$ \\
\hline
\end{tabular}


Table 1. Counts and measurements of the lectotype and paralectotype of Scorpaena dabryi, and the holotype and non-type specimens of Scorpaena miostoma (expressed as percentages of standard length) (continued).

\begin{tabular}{|c|c|c|c|c|}
\hline & \multicolumn{4}{|l|}{ Scorpaena miostoma } \\
\hline & Lectotype of $S$. dabryi & Paralectotype of $S$. dabryi & $\begin{array}{l}\text { Holotype of } \\
\text { S. miostoma }\end{array}$ & Non-type specimens \\
\hline & MNHN 6882 & MNHN 6882 & BMNH 1879.5.14.235 & $\mathrm{n}=139$ \\
\hline Longest anal-fin soft ray length & 20.9 & - & 20.9 & $20.6-25.7(23.0)$ \\
\hline Pectoral-fin ray length & 29.7 & 28.6 & 31.7 & $29.0-36.7(32.9)$ \\
\hline Pelvic-fin spine length & 17.1 & 19.0 & 15.8 & $14.5-21.0(17.5)$ \\
\hline Longest pelvic-fin soft ray length & 25.0 & 24.8 & 25.5 & $23.5-29.5(26.7)$ \\
\hline Caudal-fin length & 28.5 & 26.2 & 27.9 & $26.6-33.1(29.6)$ \\
\hline Caudal-peduncle length & 16.6 & 17.5 & 18.0 & $15.7-21.6(18.5)$ \\
\hline Caudal-peduncle depth & 9.7 & 10.1 & 10.6 & $9.7-12.1(10.8)$ \\
\hline
\end{tabular}

${ }^{a}$ Upper unbranched rays + branched rays + lower unbranched rays = total rays on left side/total rays on right side of body. ${ }^{b}$ Rakers on upper limb + on ceratohyal + on hypobranchial $=$ total rakers. ${ }^{c}$ At vertical midline of eye. ${ }^{d}$ At posterior end of preocular spine base.

tom trawl, H.-C. Ho, 18 November 2007; KAUM-I. 110867, $45.3 \mathrm{~mm}$ SL, off Ke-tzu-liao, Kaohsiung city, K. Koeda et al., 14 December 2017; KAUM-I. 110894, male, $81.2 \mathrm{~mm} \mathrm{SL}$, off Dong-gang, Pingtung county, $22^{\circ} 39^{\prime} \mathrm{N}, 120^{\circ} 24^{\prime} \mathrm{E}$, trawl, K. Koeda et al., 14 December 2017; KAUM-I. 111686, $71.2 \mathrm{~mm}$ SL, KAUM-I. 111687, $93.5 \mathrm{~mm}$ SL, KAUM-I. 111688, $87.1 \mathrm{~mm}$ SL, KAUM-I. 111689, $75.8 \mathrm{~mm} \mathrm{SL}$, KAUM-I. $111722,79.0 \mathrm{~mm}$ SL, KAUM-I. 111723, $90.3 \mathrm{~mm}$ SL, midwater trawl, 10 December 2017, other data as KAUM-I. 110894; KAUM-I. 113179, male, $90.5 \mathrm{~mm}$ SL, KAUM-I. 113497, male, $78.8 \mathrm{~mm}$ SL, KAUM-I. 113498, $89.4 \mathrm{~mm}$ SL, KAUM-I. 113676, 74.0 mm SL, KAUM-I. 113677, 90.9 mm SL, KAUM-I. 113678, male, 83.0 mm SL, KAUM-I. 113679, $78.9 \mathrm{~mm}$ SL, 5 and 8 March 2018, other data as KAUM-I. 110867; KAUM-I. 113887, 85.5 mm SL, KAUM-I. 113888, $76.4 \mathrm{~mm}$ SL, KAUM-I. 114273, $83.6 \mathrm{~mm}$ SL, KAUM-I. 114274, male, $75.0 \mathrm{~mm}$ SL, KAUM-I. 114276, $88.6 \mathrm{~mm}$ SL, KAUM-I. 114277, $88.9 \mathrm{~mm}$ SL, KAUM-I. 114278, $80.2 \mathrm{~mm}$ SL, 5 and 8 March 2018, other data as KAUM-I. 110894; KAUM-I. 115309, $90.1 \mathrm{~mm}$ SL, 8 May 2018, other data as KAUM-I. 110867; KAUM-I. 127461, male, $68.9 \mathrm{~mm}$ SL, KAUM-I. 127462, 76.2 mm SL, off Da-xi, Yilan county, bottom trawl, K. Koeda and H. Hata, 21 December 2018; KAUM-I. 151386, male, $68.8 \mathrm{~mm}$ SL, KAUM-I. 151387, $81.3 \mathrm{~mm}$ SL, KAUM-I. 151388, $85.0 \mathrm{~mm}$ SL, KAUM-I. 151389, 85.5 mm SL, KAUM-I. 151390, male, $91.1 \mathrm{~mm}$ SL, KAUM-I. 151391, male, 69.4 mm SL, KAUM-I. 151392, $92.8 \mathrm{~mm}$ SL, KAUM-I. 151393, male, $89.1 \mathrm{~mm}$ SL, KAUM-I. 151394, 74.5 mm SL, KAUM-I. 151395, $81.1 \mathrm{~mm}$ SL, off Da-xi Fishing Port, Yilan county, $24^{\circ} 56^{\prime} \mathrm{N}, 121^{\circ} 54^{\prime} \mathrm{E}$, bottom trawl, M. Matsunuma, 23 February 2017; URM-P. 23069, $82.6 \mathrm{~mm}$ SL, URM-P. 23070, $78.7 \mathrm{~mm}$ SL, URM-P. 23071, 74.2 mm SL, URM-P. 23072, 67.1 mm SL, URM-P. 23073, $66.0 \mathrm{~mm}$ SL, URM-P. 23074, 67.3 mm SL, URM-P. $35679,78.5 \mathrm{~mm}$ SL, precise locality unknown, trawl, T. Yoshino, 8 May 1989.

\section{Results and Discussion}

Synonymy. Scorpaena dabryi has remained poorly known, with no further records since the original description by Sauvage (1878) as a new species based on two (syntypes) specimens (MNHN 6882, 71.0-75.5 mm SL). Subsequently, Fricke et al. (2019) treated $S$. dabryi as a senior synonym of Neomerinthe procurva Chen, 1981. However, examination of the type specimens in the present study revealed them to be conspecific with S. miostoma Günther, 1877, there being no differences in their morphological characters, including counts and proportional measurements, compared with those of the holotype and non-type specimens of S. miostoma (Table 1). Accordingly, $S$. dabryi is considered to be conspecific with and a junior synonym of S. miostoma. For nomenclatural stability, the larger and better condition syntype [MNHN 6882 (75.5 mm SL; Fig. 1A)] is designated herein as lectotype of $S$. dabryi, the smaller syntype [MNHN 6882 (71.0 mm SL; Fig. 1B)] therefore becoming a paralectotype.

Description of the type specimens of Scorpaena dabryi. Selected meristic characters and proportional measurements (as percentages of SL) are shown in Table 1. Data for the lectotype are presented first, followed by that for the paralectotype in parentheses (if different). Body moderately compressed anteriorly, progressively more compressed posteriorly, relatively shallow, depth much less than head length. Nape and anterior of body not highly arched. Dorsal fin with 12 spines and 9 soft rays; 4th spine longest; 5 th to 11 th spines becoming progressively shorter; length of last spine subequal to that of 2 nd spine; all soft rays branched; posterior branch of last soft ray joined by membrane to caudal peduncle for more than four-fifths its length. Anal fin with 3 spines and 5 soft rays; 1st spine shortest; 2nd longest, its length greater than 4th dorsal-fin spine length; all soft rays branched. Pectoral fin with 16 (17) 2 upper unbranched rays, 6 (5) branched rays, 8 (10) lower unbranched rays] and 17 rays on left and right sides of body, respectively; posterior tip not reaching to beyond level with base of 11th dorsal-fin spine. Scales above lateral line 5 (not observed in paralectotype due to poor condition of head and body). Scale rows between last dorsal-fin spine base and lateral line 7 (not observed in paralectotype). Predorsal scale rows 5 (not observed in paralectotype). Gill rak- 

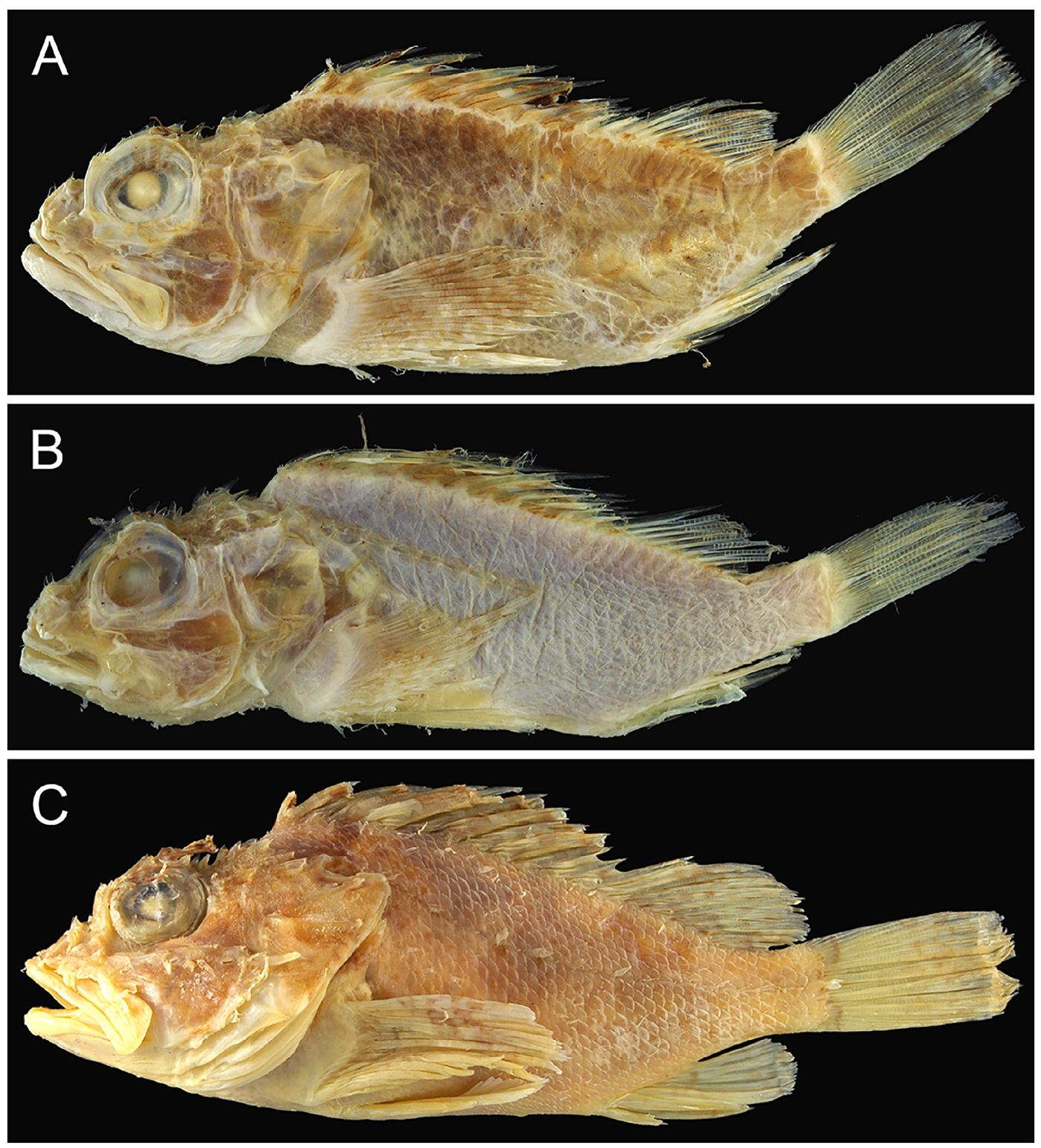

Fig. 1. Photographs of Scorpaena miostoma. A, lectotype of $S$. dabryi (MNHN 6882, male, $75.5 \mathrm{~mm} \mathrm{SL);} \mathrm{B,} \mathrm{paralectotype} \mathrm{of} S$. dabryi (MNHN 6882, 71.0 mm SL); C, holotype of S. miostoma (BMNH 1879.5.14.235, 106.4 mm SL).

ers on upper limb 4 (5) and lower limb 10 (9) [8 (7) and 2 rakers on ceratohyal and hypobranchial, respectively)], total 14, short and spinous; fourth gill slit closed by membrane. Pectoral-fin base and anteroventral surface of body, including space between pelvic fins and abdomen, with embedded cycloid scales. Lateral surface of body covered with ctenoid scales, remaining body abdomen surface covered with wellexposed cycloid scales. Exposed ctenoid scales from area behind eye to below lower posttemporal spine and posterior area between opercular spines (indicated by a few remaining scales; not observed in paralectotype). Posterior margin of maxilla just reaching a vertical at posterior margin of pupil. Lateral surface of maxilla smooth, without median ridge, tentacles or scales. No dermal flap on pectoral-fin axil. Suborbital pit and coronal and pretympanic spines absent. Median interorbital ridge absent (present in paralectotype, ridge low, short, beginning just behind posterior margin of ascending process of premaxilla and ending about midline between posterior end of preocular spine bases). Nasal spine simple, conical, directed upwards. Anterior nostril with a distinct tentacle, its length greater than nasal spine. Interorbital ridges moderately developed, separated by a relatively deep channel. Preocular, supraocular, and postocular spines simple; preocular spine shorter than preocular and postocular spines; preocular spine associated with a large tentacle, its length greater than pupil diameter. Tympanic, pterotic, parietal and nuchal spines simple, strongly pointed. Occipital pit relatively shallow; a distinct ridge anterior to occipital pit slightly curved posteromedially in dorsal view; an indistinct straight transverse ridge in rear of occipital pit between bases of nuchal spines. Sphenotic with 2 small sharp spines. Postorbital smooth without pointed spines. Lateral lacrimal ridge present. Lateral surface of lacrimal with a single pointed spine. Anterior lacrimal spine with an additional small spinous point on posterior margin, directed anteriorly; anterior lacrimal spine associated with a short tentacle. 


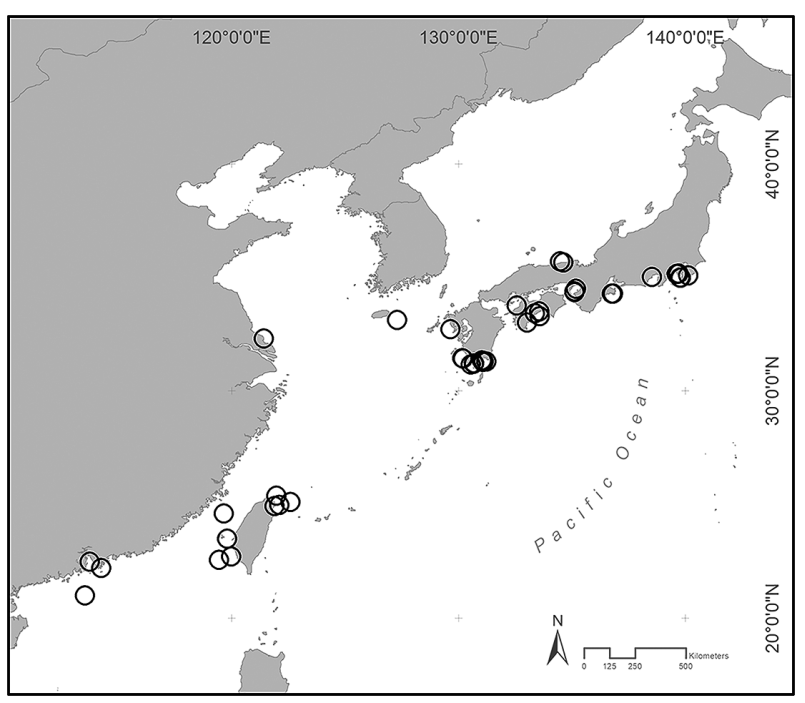

Fig. 2. Distributional records of Scorpaena miostoma based on collected specimens examined in this study.

Posterior lacrimal spine simple, directed ventroposteriorly, its length greater than anterior lacrimal spine; posterior lacrimal spine associated with a large tentacle. Suborbital ridge with 3 spines, posterior end of 1 st spine base on a vertical line through posterior margin of pupil, second spine extending beyond orbit, third spine at end of suborbital ridge. Preopercle with 5 pointed spines; uppermost largest with a supplemental preopercular spine on base. Upper and lower opercular spines simple, upper spine with a low median ridge, lower spine with a distinct median ridge. Cleithral spine flattened, strongly pointed. A black blotch on membrane of spinous dorsal fin between 6th and 9th spines (absent in paralectotype).

Variations in Scorpaena miostoma. The following characters of S. miostoma, based on examination of 139 non-type specimens, showed several variations: (morphometric and selected meristic data given in Table 1). One specimen (the smallest, $21.5 \mathrm{~mm} \mathrm{SL}$ ) had all pectoral-fin rays unbranched (larger individuals usually with 2 nd to 7 th rays branched; see Table 1). Anterior lacrimal spine usually with an additional second small spine (without or with 2 additional spines; 6 and 8 specimens of all specimens examined, respectively) on posterior margin. Sphenotic with 1-4 (usually 2 on each side) small pointed spines. Postorbital serrated or smooth, without spines (rarely with 1 or 2 tiny spines; 4 specimens of all specimens examined). Median interorbital ridge absent (rarely present with short ridge, beginning just behind posterior margin of ascending process of premaxilla and ending about midline between posterior ends of preocular spine bases). A large dense black blotch in males on outer margin of membrane of spinous dorsal fin from 6th to 10th (usually 7th-9th) spines (absent in females).

Comparisons. Examination of all available type and non-type specimens regarded as valid Indo Pacific species of Scorpaena, in addition to the original descriptions, revealed that they could be separated into three groups, based on the condition of the lateral lacrimal spine. Those lacking the spine included eight species [S. bulacephala Motomura, Last and Yearsley, 2005, S. colorata (Gilbert, 1905), S. decemradiata Fricke, Golani, Appelbaum-Golani and Zajonz, 2018, S. gasta Motomura, Last and Yearsley, 2006, S. neglecta Temminck and Schlegel, 1843, S. papillosa (Schneider and Forster, 1801), S. scrofa Linnaeus, 1758 and S. sumptuosa Castelnau, 1875]; those with two points on the spine, three species (S. cardinalis Solander and Richardson, 1842, S. jacksoniensis Steindachner, 1866 and S. orgila Eschmeyer and Allen, 1971); and those with a single point, the six remaining species (S. miostoma, S. brevispina Motomura and Senou, 2008, S. lacrimata Randall and Greenfield, 2004, S. onaria Jordan and Snyder, 1900, S. pepo Motomura, Poss and Shao, 2007 and S. pele Eschmeyer and Randall, 1975) (Eschmeyer and Randall 1975; Randall and Greenfield 2004; Motomura et al. 2005a, b, 2006, 2007, 2009, 2011; Motomura and Senou 2008; Fricke et al. 2018; Wibowo and Motomura 2019; this study). However, S. miostoma can be distinguished from other species in the third group by having relatively lower numbers of pectoral-fin rays (15-17, usually 16; rarely 15 or 17,3 and 8 specimens of all examined specimens, respectively) (vs. 16-17; usually 17 in the other species, except for $S$. pepo) (Eschmeyer and Randall 1975; Randall and Greenfield 2004; Motomura et al. 2006; Motomura and Senou 2008), scale rows in the longitudinal series (43-47, usually 45) (vs. 61 in S. lacrimata; Randall and Greenfield 2004), and gill rakers (12-15, usually 13 or 14 ) (vs. 14-17; usually 16 or 17 in S. brevispina, S. onaria, and S. pele) (Eschmeyer and Randall 1975; Randall and Greenfield 2004; Motomura et al. 2006; Motomura and Senou 2008).

Furthermore, only four (including S. miostoma) of the six species of the third group co-occur in the northwestern Pacific (including Japanese waters), whereas the two remaining species, S. lacrimata and S. pele have restricted distributions in the Society Islands and Hawaiian Islands, respectively. In addition to the number of pectoral-fin rays and gill rakers, S. miostoma can also be distinguished from the northwestern Pacific congeners by having a shallow occipital pit ( $v s$. extremely deep in S. brevispina; Motomura and Senou 2008), absence of a median interorbital ridge (a short ridge rarely present) ( $v s$. median interorbital ridge present, well developed in S. onaria and S. pepo; Motomura et al. 2005b, fig. 4; Motomura et al. 2007), lesser relative lower body depth [32.3-39.9\% (mean 36.1\%) of SL] ( $v s$. greater body depth, $36.4-45.1 \%$ of SL in S. onaria and $S$. pepo; Motomura et al. 2007), the lateral line sloping moderately downward above the anterior $1 / 2$ of the pectoral fin (vs. sloping steeply downward above the anterior $1 / 2$ of the pectoral fin in S. onaria and S. pepo; Motomura et al. 2007; Nakabo 2002: 580, unnumbered figs.), a smaller body (maximum size $133.4 \mathrm{~mm}$ SL in this study) (vs. larger body, up to $265.2 \mathrm{~mm}$ SL in S. onaria and $245.1 \mathrm{~mm}$ SL in S. pepo; Motomura et al. 2005b, 2007), and the fresh and preserved coloration without small distinct black spots scattered on the head and body (Fig. 3) (vs. many small distinct black spots scattered on the body in S. onaria, and head and body in $S$. pepo) (Motomura et al. 2005b, fig. 2; Motomura et al. 2007, figs 1, 2; Wang 2011: 325, unnumbered figs). 

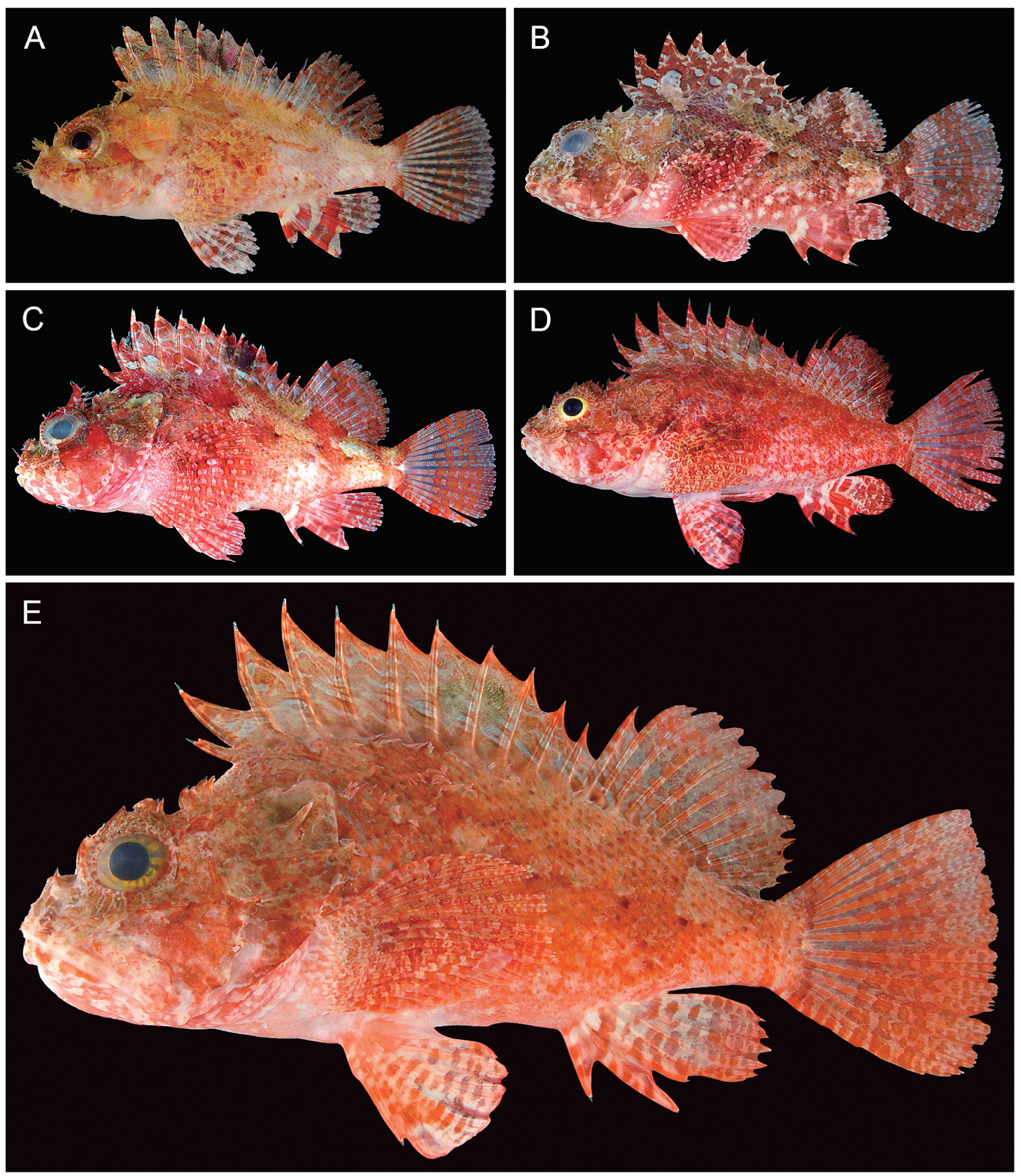

Fig. 3. Life stages of Scorpaena miostoma. A, KAUM-I. 71264, male, $43.8 \mathrm{~mm}$ SL; B, KAUM-I. 25862, 62.3 mm SL; C, KAUM-I. 71449, male, 81.5 mm SL; D, KAUM-I. 30796, 108.2 mm SL; E, KAUM-I. 10014, male, 124.4 mm SL.

Morphological ontogenetic changes. Changes in some body proportions with growth in the genus Scorpaena, viz., S. bulacephala, S. cardinalis, S. jacksoniensis, S. neglecta, and $S$. onaria, have been reported by many authors (e.g., Motomura et al. 2005a, fig. 4; Motomura et al. 2005b, fig. 7; Motomura et al. 2011, fig. 10; Wibowo and Motomura 2019, fig. 6). Analyses of 42 measurements showed that some features in S. miostoma also transformed remarkably relative to SL with growth, orbit diameter, occipital pit width and length, and predorsal-fin and all fin ray lengths becoming remarkably shorter with growth, whereas the space between the ventral orbital margin and suborbital ridge, postorbital length, and body width became remarkably greater [selected characters presented in Fig. 4; smallest specimen $(21.5 \mathrm{~mm}$ SL) excluded]. All body dimensions changing with growth (except body width) in S. miostoma, noted herein, have pre- viously been reported as changing with growth in $S$. bulacephala, S. cardinalis, S. jacksoniensis, and S. neglecta. However, allometric changes in head growth (head, upper jaw and snout lengths, and maxilla depth), all previously reported in the latter species, were not apparent in S. miostoma.

Distribution. Scorpaena miostoma is distributed only in the northwestern Pacific Ocean, including China, Korea, Japan and Taiwan (Shimizu 1984; Motomura and Iwatsuki 1997; Shimizu and Hatooka 1997; Nakabo 2002; Wang 2011; this study, Fig. 2). Specimens examined in this study had been collected from shallow to deep waters, ranging between $7-500 \mathrm{~m}$. The species is most likely to prefer temperate waters, since it tends to inhabit deeper waters in lower latitudes; it is common in tidal pools in Japan, but has been mostly collected from deep water $(>400 \mathrm{~m})$ off Taiwan.

Comparative material examined. All Indo-Pacific spe- 

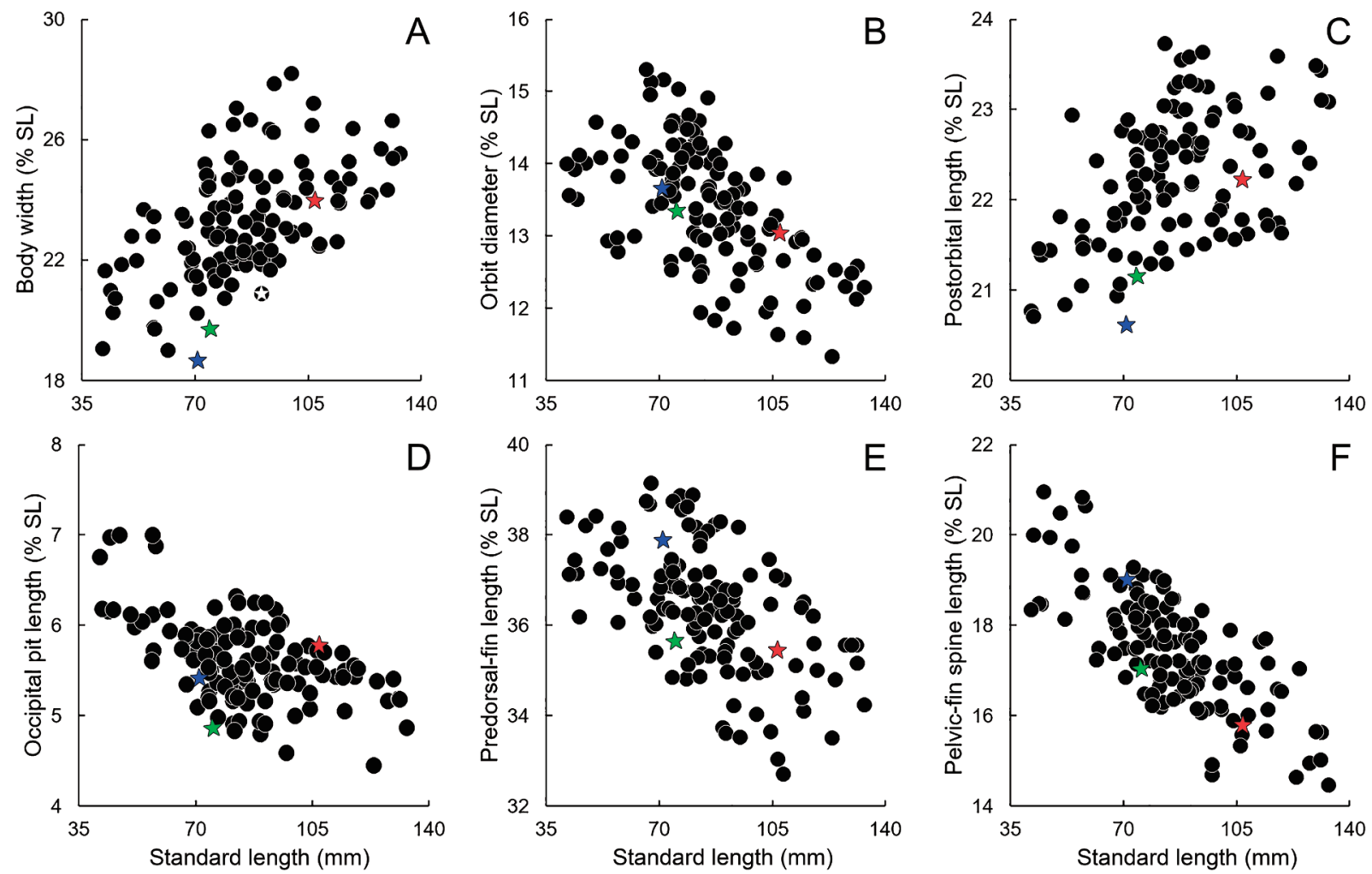

Fig. 4. Relationships of A, body width; B, orbit diameter; C, postorbital length; D, occipital pit length; E, predorsal-fin length; F, pelvic-fin spine length (all as \% of standard length) to standard length in Scorpaena miostoma. Closed red, green and blue stars indicate holotype of S. miostoma, and lectotype and paralectotype of S. dabryi, respectively.

cies of Scorpaena (except for Scorpaena decemradiata Fricke, Golani, Appelbaum-Golani and Zajonz, 2018), viz., S. brevispina Motomura and Senou, 2008; S. bulacephala Motomura, Last and Yearsley, 2005; S. cardinalis Solander and Richardson, 1842; S. colorata (Gilbert, 1905); S. gasta Motomura, Last and Yearsley, 2006; S. jacksoniensis Steindachner, 1866; S. neglecta Temminck and Schlegel, 1843; S. onaria Jordan and Snyder, 1900; S. orgila Eschmeyer and Allen, 1971; S. papillosa (Schneider and Forster, 1801); S. pepo Motomura, Poss and Shao, 2007; S. pele Eschmeyer and Randall, 1975; S. scrofa Linnaeus, 1758; and S. sumptuosa Castelnau, 1875, examined in this study are listed in Motomura et al. (2005a, b, 2006, 2007, 2009, 2011), Motomura and Senou (2008), and Wibowo and Motomura (2019).

\section{Acknowledgments}

We are especially grateful to S.-P. Huang (ASIZ), J. Maclaine (BMNH), H. Endo (BSKU), D. Catania and M. Hoang (CAS), H. Kawase (CMNH), S. Kimura (FRLM), P. Pruvost, R. Causse, Z. Gabsi, J. Pfliger, and P. Béarez $(\mathrm{MNHN})$, S. Matsui and K. Hatooka $(\mathrm{OMNH})$, K. Miyamoto (URM), and J. Williams, S. Raredon, K. Murphy, S. Smith, E. Wibur, and D. Pitassy (USNM) for opportunities to examine specimens, and M. Matsunuma (Kindai University, Japan) for recording some specimen data. We are very grateful to G. Hardy (Ngunguru, New Zealand) for reading the manuscript and assisting with English. This study was supported in part by JSPS KAKENHI Grant Numbers JP19770067, JP26241027, JP24370041, JP23580259, and JP26450265; the JSPS Core-to-Core Program: B Asia-Africa Science Platforms; the "Biological Properties of Biodiversity Hotspots in Japan" project of the National Museum of Nature and Science, Tsukuba, Japan; "Establishment of Research and Education Network on Biodiversity and Its Conservation in the Satsunan Islands" project of Kagoshima University adopted by the Ministry of Education, Culture, Sports, Science and Technology, Japan; and the "Island Research" project of Kagoshima University.

\section{References}

Chen, L.-C. 1981. Scorpaenid fishes of Taiwan. Quarterly Journal of the Taiwan Museum 34: 1-60.

Ebert, D. A., Ho, H.-C., White, W. T., and de Carvalho, M. R. 2013. Introduction to the systematics and biodiversity of sharks, rays, and chimaeras (Chondrichthyes) of Taiwan. Zootaxa 2752: 5-19.

Eschmeyer, W. N. 1965. Western Atlantic scorpionfishes of the genus Scorpaena, including four new species. Bulletin of Marine Science 15: 84-164.

Eschmeyer, W. N. and Randall, J. E. 1975. The scorpaenid fishes of the Hawaiian Islands, including new species and new records (Pisces: Scorpaenidae). Proceedings of the California Academy of Sciences (Series 4) 40: 265-333.

Fricke, R., Golani, D., Appelbaum-Golani, B., and Zajonz, U. 2018. Scorpaena decemradiata new species (Teleostei: Scorpaenidae) from the Gulf of Aqaba, northern Red Sea, a species distinct from 
Scorpaena porcus. Scientia Marina 82: 1-16.

Fricke, R., Eschmeyer, W. N., and Van der Laan, R. (Eds) 2019. Eschmeyer's catalog of fishes: genera, species, references. Available at http://researcharchive.calacademy.org/research/ichthyology/cata log/fishcatmain.asp (28 February 2019).

Motomura, H. 2004a. New species of scorpionfish, Scorpaena cocosensis (Scorpaeniformes: Scorpaenidae) from the Cocos Islands, Costa Rica, eastern Pacific Ocean. Copeia 2004: 818-824.

Motomura, H. 2004b. Revision of the scorpionfish genus Neosebastes (Scorpaeniformes: Neosebastidae) with descriptions of five new species. Indo-Pacific Fishes 37: 1-75.

Motomura, H. and Iwatsuki, Y. 1997. A preliminary report of scorpaenid, synanceiid, tetrarogid and aploactinid fishes in Miyazaki waters, southern Japan. Bulletin of the Faculty of Agriculture of Miyazaki University 44: 127-138.

Motomura, H., Last, P. R., and Yearsley, G. K. 2005a. Scorpaena bulacephala, a new species of scorpionfish (Scorpaeniformes: Scorpaenidae) from the northern Tasman Sea. Zootaxa 1043: 17-32.

Motomura, H., Last, P. R., and Yearsley, G. K. 2006. New species of shallow water scorpionfish (Scorpaenidae: Scorpaena) from the central coast of Western Australia. Copeia 2006: 360-369.

Motomura, H., Ogihara, G., Meguro, M., and Matsunuma, M. 2009. First records of the Pumpkin Scorpionfish, Scorpaena pepo (Scorpaenidae), from Japan. Biogeography 11: 139-143.

Motomura, H., Paulin, C. D., and Stewart, A. L. 2005b. First records of Scorpaena onaria (Scorpaeniformes: Scorpaenidae) from the southwestern Pacific Ocean, and comparisons with the Northern Hemisphere population. New Zealand Journal of Marine and Freshwater Research 39: 865-880.

Motomura, H., Poss, S. G., and Shao, K.-T. 2007. Scorpaena pepo, a new species of scorpionfish (Scorpaeniformes: Scorpaenidae) from northeastern Taiwan, with a review of S. onaria Jordan and Snyder. Zoological Studies 46: 35-45.

Motomura, H. and Senou, H. 2008. A new species of the scorpionfish genus Scorpaena (Scorpaenidae) from Izu Peninsula, Pacific coast of Japan. Journal of Fish Biology 72: 1761-1772.

Motomura, H., Struthers, C. D., McGrouther, M. A., and Stewart, A. L. 2011. Validity of Scorpaena jacksoniensis and a redescription of $S$. cardinalis, a senior synonym of $S$. cookii (Scorpaeniformes: Scorpaenidae). Ichthyological Research 58: 315-332.

Motomura, H., Yoshino, T., and Takamura, N. 2004. Review of the scorpionfish genus Scorpaenopsis (Scorpaeniformes: Scorpaenidae) in
Japanese waters with three new records and an assessment of standard Japanese names. Japanese Journal of Ichthyology 51: 89-115. [In Japanese]

Nakabo, T. 2002. Scorpaenidae. Pp. 565-595, 1519-1522. In: Nakabo, T. (Ed.) Fishes of Japan with Pictorial Keys to the Species, English Edition. Tokai University Press, Tokyo.

Poss, S. G. 1999. Scorpaenidae. Pp. 2291-2352. In: Carpenter, K. E. and Niem, V. H. (Eds) FAO Species Identification Guide for Fishery Purposes. The Living Marine Resources of the Western Central Pacific. Vol. 4. Bony Fishes Part 2 (Mugilidae to Carangidae). FAO, Rome.

Randall, J. E. and Eschmeyer, W. N. 2002 (dated 2001). Revision of the Indo-Pacific scorpionfish genus Scorpaenopsis, with descriptions of eight new species. Indo-Pacific Fishes 34: 1-79.

Randall, J. E. and Greenfield, D. W. 2004. Two new scorpionfishes (Scorpaenidae) from the South Pacific. Proceedings of the California Academy of Sciences 55: 384-394.

Sauvage, H. E. 1878. Description de poissons nouveaux ou imparfaitement connus de la collection du Muséum d'Histoire Naturelle. Famille des Scorpénidées, des Platycéphalidées et des Triglidées. Nouvelles Archives du Muséum d'Histoire Naturelle, Paris (Série 2) 1: 109-158, 2 pls.

Sabaj, M. H. 2016. Standard symbolic codes for institutional resource collections in herpetology and ichthyology: an online reference. Version 6.5 (16 August 2016). American Society of Ichthyologists and Herpetologists, Washington, DC. Available at http:// www.asih.org/resources/standard-symbolic-codes-institutionalresource-collections-herpetologyichthyology $\quad(27 \quad$ November 2018).

Shimizu, T. 1984. Scorpaena miostoma. Text, p. 314, Pl., p. 280. In: Masuda, H., Amaoka, K., Araga, C., Uyeno, T., and Yoshino, T. (Eds) The Fishes of the Japanese Archipelago. Tokai University Press, Tokyo.

Shimizu, T. and Hatooka, K. 1997. New records of the fishes from the Seto Inland Sea. Izu Oceanic Park Diving News 8: 2-6. [In Japanese]

Wang, W.-H. 2011. Fishes of Taiwan. National Museum of Marine Biology and Aquarium, Pingtung, 896 pp. [In Taiwanese]

Wibowo, K. and Motomura, H. 2019. Redescription of the Indo-West Pacific scorpionfish Scorpaena neglecta Temminck \& Schlegel 1843 , a senior synonym of four nominal species (Teleostei: Scorpaenidae). Zootaxa 4619: 311-329. 